The Classical Quarterly

http://journals.cambridge.org/CAQ

Additional services for The Classical Quarterly:

Email alerts: $\underline{\text { Click here }}$

Subscriptions: $\underline{\text { Click here }}$

Commercial reprints: Click here

Terms of use : $\underline{\text { Click here }}$

\title{
TIBULLUS' ELEGIAC UNDERWORLD
}

\section{B. T. HOUGHTON}

The Classical Quarterly / Volume 57 / Issue 01 / May 2007, pp 153 - 165

DOI: 10.1017/S0009838807000146, Published online: 15 May 2007

Link to this article: http://journals.cambridge.org/abstract_S0009838807000146

How to cite this article:

L. B. T. HOUGHTON (2007). TIBULLUS' ELEGIAC UNDERWORLD. The Classical Quarterly,57, pp 153-165 doi:10.1017/ S0009838807000146

Request Permissions : $\underline{\text { Click here }}$ 


\section{TIBULLUS’ ELEGIAC UNDERWORLD}

One of the earliest and most extensive accounts of the underworld in Roman elegiac poetry is to be found in the third poem of Tibullus' first book. ${ }^{1}$ Sundered from Delia's embrace through the obligations of military service, and prevented by illness from following Messalla's campaign to the East, the poet lies sick on Phaeacia (the island of Corfu) and muses upon the contrast between the wretchedness of his-and mankind's - present condition, on the one hand, and the felicity of the Golden Age and the blessings he anticipates will await him after death, on the other. The descriptions of Elysium and Tartarus in the second half of the poem (1.3.57-82) are carefully integrated into the thematic structure of the whole: scholars have pointed to the appositeness of incorporating a Nekuia in a poem pervaded by echoes of the Odyssey, ${ }^{2}$ and various correspondences have been detected between the two sections of the underworld and the lavish portrait of primeval simplicity representing Tibullus' conception of the aurea aetas. ${ }^{3}$ Within the context of its elegy, then, our poetic tour of the world below can be seen to fit into a tightly controlled complex of unifying themes. But these twenty-six lines of infernal gazetteer are also of considerable interest in their own right, as a model of the means by which an author can manipulate traditional material to fulfil a particular generic purpose.

Having envisaged his death and penned his epitaph, Tibullus turns to the sequel $(1.3 .57-64)$ :

sed me, quod facilis tenero sum semper Amori,
ipsa Venus campos ducet in Elysios.
hic choreae cantusque vigent, passimque vagantes

* I am very grateful to Professor M. D. Reeve, Dr William Fitzgerald, Dr Emily Gowers and Professor Roy K. Gibson, and to CQ's anonymous referee, for comments on previous drafts of this article. Funding for the period during which this research was carried out was provided by the AHRC of the British Academy.

1 The generally accepted chronological sequence Propertius $1 \Rightarrow$ Tibullus $1 \Rightarrow$ Propertius 2 suggests that Prop. 1.19.7-18 may be the only earlier elegiac description to survive - but see now P. E. Knox, 'Milestones in the career of Tibullus', CQ 55 (2005), 204-16, who argues for the priority of Tibullus' first collection.

${ }^{2}$ For Odyssean echoes in 1.3 see B. Moßbrucker, Tibull und Messalla (Bonn, 1983), 34-55; R. J. Ball, Tibullus the Elegist, Hypomnemata 77 (Göttingen, 1983), 50-65 (but NB 79); D. F. Bright, Haec mihi fingebam: Tibullus in his World (Leiden, 1978) 16-37, esp. 29, 31, 34; P. Lee-Stecum, Powerplay in Tibullus (Cambridge, 1998) 103-4; D. F. Kennedy, The Arts of Love: Five Studies in the Discourse of Roman Love Elegy (Cambridge, 1993), 16, 49; F. Cairns, Tibullus: A Hellenistic Poet at Rome (Cambridge, 1979), 44-5, 46; D. P. Harmon, ANRW 2.16 .3 (1986), 1920; H. Eisenberger, 'Der innere Zusammenhang der Motive in Tibulls Gedicht I,3', Hermes 88 (1960), 188-97, at 191, 194, 196. Reservations from M.-P. Pieri in Munus amicitiae: scritti in memoria di Alessandro Ronconi (Florence, 1988), 2.98-111, at 98-101, 109, n. 33; Murgatroyd ad 1.3 intro. (p. 100); W. Wimmel, Der frühe Tibull (Munich, 1968), 179-80, 218, n. 83.

3 Maltby ad 1.3 intro., ad 57-66, 77-8; Lee-Stecum (n. 2), 120; A. M. Morelli, 'I "Saturnia regna" nell'elegia 1, 3 di Tibullo', MD 26 (1991), 175-87 at 182; Moßbrucker (n. 2), 50-1; R. Whitaker, Myth and Personal Experience in Roman Love-Elegy, Hypomnemata 76 (Göttingen, 1983), 72; H. Geiger, Interpretationen zur Gestalt Amors bei Tibull (Zürich, 1978), 13, n. 1; C. Campbell, YClS 23 (1973), 52 with n. 11; R. Hanslik, 'Tibulls Elegie I 3', in W. Wimmel (ed.), Forschungen zur römischen Literatur. Festschrift zum 60. Geburtstag von Karl Büchner, Teil I (Wiesbaden, 1970), 138-45, at 144. 
dulce sonant tenui gutture carmen aves;

fert casiam non culta seges, totosque per agros

floret odoratis terra benigna rosis;

ac iuvenum series teneris immixta puellis

ludit, et adsidue proelia miscet Amor.

Commentators have remarked on the 'eroticisation' of Elysium in this passage, a note struck almost immediately in lines $57-8$ with the declaration that it is Tibullus' openness to love that will bring about his reward in the afterlife. Even more striking, perhaps, is the image of Venus leading his soul to the plains of Elysium: since at least the final book of the Odyssey the role of $\psi v \chi \circ \pi \circ \mu \pi$ ós, the escort of souls, had been ascribed to Hermes or his Roman equivalent Mercury, ${ }^{4}$ and it is in this capacity that he appears in the standard iconography of Greco-Roman tomb art. ${ }^{5}$ The appearance of Venus in this context has alarmed historians of religion, leading to a frantic search for some kind of precedent for the intervention of the goddess of love in matters eschatological. 'Venus' here has been variously identified with Isis, whose aid is invoked earlier in the poem (1.3.23-32), ${ }^{6}$ with the Syrian divinity Astarte, ${ }^{7}$ or with some other death-goddess; evidence has been sought for the involvement of Venus in Roman funerary cult. ${ }^{8}$ Certainly Venus/Aphrodite appears as a symbolic image in the repertoire of Hellenistic and Roman sarcophagus decoration, ${ }^{9}$ but there is never any suggestion of her usurping Mercury/Hermes' psychopompic function, as here. ${ }^{10}$

Surely the least far-fetched solution is to conclude that Venus here represents none other than herself (ipsa, 58) - after all, what could be more fitting than for a poet of love to be conducted to blessedness by his own patron goddess? The introduction of

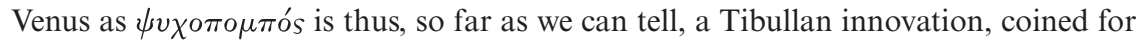
the occasion; ${ }^{11}$ the uncomfortable reaction of scholars to this amatory twist could easily be seen as a confirmation that the purpose of Tibullus' new escort is, precisely, to confound his readers' expectations, and lead them to question why this Mercurial task should here devolve on to the goddess of love.

${ }^{4}$ Hom. Od. 24.1-10, 99-100; further refs. in C. Pascal, Le credenze d'oltretomba nelle opere letterarie dell'antichità classica (Catania, 1912), 1.78-80 with 79, n. 4; R. Garland, The Greek

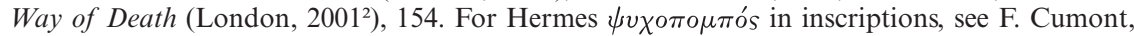
After Life in Roman Paganism (New Haven-London, 1922), 105, 138, 163-4; id., Lux perpetua (Paris, 1949), 301 with n. 4.

5 See the sarcophagus relief in F. Cumont, Recherches sur le symbolisme funéraire des Romains (Paris, 1942), pl.I, fig.3 (ibid. 29, n. 2 for bibliography); also Cumont (n. 4, 1949), 214, 297; id. (n. 4, 1922), 85 with n. 35; A. Donati (ed.), Romana pictura: la pittura romana dalle origini all'età Bizantina (Milan, 1998), 116, pl. 3, 175, pl. 63 (late). In general, LIMC 5.1(+2) s.v. HerMES, 598-615; J. H. Oakley, Picturing Death in Classical Athens (Cambridge, 2004), 137-41 with figs. 68, 70-2, 100, 102-5, pl. IVB; Garland (n. 4), 54-5 with 11, fig. 4, 57, fig.10, 154.

6 Wimmel (n. 2), 187, n. 27, 204-6.

7 P. Grimal, 'Vénus et l'immortalité (à propos de Tibulle, I,3,37 et suiv.)', in Hommages à Waldemar Deonna, Collection Latomus 28 (Brussels, 1957), 258-62 at 261, n. 5, raises this possibility via the Etruscan intermediary Turan (cf. R. Schilling, La religion romaine de Vénus depuis les origines jusqu'au temps d'Auguste [Paris, 1982²], 205-6).

8 See Harmon (n. 2), 1924-7; Schilling (n. 7), 204-6; Cumont (n. 5), 43 with n. 4; G.-C. Picard, 'La Vénus funéraire des Romains', MEFRA 56 (1939), 121-35.

9 Cumont (n. 5), 20-2 with Pl.I, fig.2; Grimal (n. 7), 261-this evidence is late, however: Harmon (n. 2), 1923-4, 1926.

10 Despite the pleading of Grimal (n. 7), 260, Tibullan influence on CLE 1109.27-8 cannot be discounted: cf. Wimmel (n. 2), 206, n. 62.

11 Harmon (n. 2), 1927; also Whitaker (n. 3), 71 n.14; A. Foulon, REL 78 (2000), 98-9. 
In other respects too, Tibullus' vision of felicity in the afterlife seems particularly well adapted to the posthumous fate of a devotee of Venus: amongst its beneficiaries we hear only of lovers (illic est, cuicumque rapax Mors venit amanti, 65), ${ }^{12}$ and various elements in the topography of this Elysian idyll could also be seen in an amatory light. But how far is the erotic resonance of these details merely incidental, a fortuitous convergence of the motifs of love poetry with traditional features of the underworld familiar to Tibullus' first-century audience? The fragrant roses strewn totos per agros at lines 61-2, for example, may recall the time-honoured association of this flower with Venus, especially in combination with myrtea serta two lines later, myrtle being another plant habitually associated with the goddess. But both types of flora occur also in non-elegiac descriptions of Elysium or the Isles of the Blessed, ${ }^{13}$ and the landscape of the afterlife in Roman tomb art frequently takes the form of 'gardens glowing with flowers, fruits, and gorgeous birds' - the final item in this catalogue seemingly compromising any assumption that the aves of lines 59-60 possess a specific and immediately identifiable erotic character. ${ }^{14}$ Similar parallels can be found for the appearance of dancing (59), song (59) and spices (61) in an infernal setting. ${ }^{15}$ Is Tibullus' eroticization of Elysium, then, when viewed with an awareness of previous literary and artistic treatments of the theme, less comprehensive or less pronounced than critics have wanted to make it?

To claim that the picture of Elysium at Tibullus 1.3.57-66 betrays no sign of an erotic slant imposed upon traditional material would be perverse: the presence of Venus as $\psi v \chi 0 \pi о \mu \pi$ ós at the outset is sufficient to dispel any such attempt at reductivism. But the particular emphases of the elegist's vision of the rewards that await the virtuous lover can be discerned only if we recognize the way in which he has transformed the inherited associations likely to colour any account of the world below. To the conventional paraphernalia of the blessed afterlife-flowers, myrtle, birds - Tibullus has given a distinctive amatory twist, bringing out the latent eroticism of this iconography not simply by its inclusion in his version of the underworld, but by the specific literary register he employs to describe both these and other constituents of his Elysium. The birds, for instance, are depicted as singing tenui gutture (60), the quality of tenuitas being a literary and aesthetic concept highly prized among practitioners of the elegiac genre (see commentators ad loc.); the group

12 It is widely assumed that Tibullus' Elysium is exclusively for lovers; but, as Whitaker (n. 3), 71 points out, the language used does not preclude the possibility that there may be other regions of Elysium the poet is choosing not to emphasize (cf. also Smith ad 59-64).

13 Roses: Maltby, and Murgatroyd ad 1.3.61-2; R. Dimundo, Properzio 4, 7: dalla variante di un modello letterario alla costante di una unità tematica (Bari, 1990), ad Prop. 4.7.60. Myrtle also associated with Elysium: Lee-Stecum (n. 2), 121, n. 44; refs. in Maltby ad 1.3.65-6.

14 Quotation from J. M. C. Toynbee, Death and Burial in the Roman World (London, 1971), 39; cf. ibid. 95 (cepotaphia as a reflection of Elysium; also J. Prieur, La mort dans l'antiquité romaine [Rennes, 1986], 39); E. Courtney, Musa Lapidaria: A Selection of Latin Verse Inscriptions (Atlanta, 1995), 184.18n.; J. Griffin, Latin Poets and Roman Life (London, 1985), 160; Cumont (n. 5), 29; id. (n. 4, 1949), 68, 71 ('délicieux jardins'), 326; A. Brelich, Aspetti della morte nelle iscrizioni sepolcrali dell' impero romano (Budapest, 1937), 45. For an example of such mystic landscapes, see Donati (n. 5), 175, pl. 63, 131-2 (late third century A.D.).

15 Maltby ad 1.3.59-60, 61-2; Dimundo (n. 13) ad Prop. 4.7.61-2; cf. Cairns (n. 2), 52 -Elysian scenery 'can all be paralleled from non-specific descriptions of the Islands of the Blessed'; J. Warden, Fallax opus: Poet and Reader in the Elegies of Propertius, Phoenix suppl. vol. 14 (Toronto-Buffalo-London, 1980), 39 with 123, n. 3. Spices could also have a funerary resonance, as indicated by Tib. 1.3 .7 (see also Prop. 4.7.32; Stat. Silv. 2.1.160-2, 2.6.86-90; [Tib.] 3.2.23-5, with Navarro Antolín, Lygdamus: Corpus Tibullianum III.1-6. Lygdami Elegiarum Liber, Mnemosyne suppl. 154 [Leiden-New York-Cologne, 1995], ad loc.). 
of young men teneris immixta puellis (63) suggests the favourite pastime of the elegiac lover, and the characteristic attribute of the puellae with whom he pursues it: ${ }^{16}$ and the verb used to describe this activity, ludit (64), is also reminiscent of the vocabulary of elegy, where it commonly denotes 'play' of a sexual nature. ${ }^{17}$ Finally, the observation that Love 'constantly stirs up battles' (adsidue proelia miscet, 64) on the Elysian plains introduces the quintessential elegiac topos of militia amoris - an especially piquant intervention if we recall the predominantly martial connotations of Elysium in earlier literature. ${ }^{18}$

There has been considerable resistance among commentators to the proposition that Tibullus' eroticization of the underworld might also carry a poetic resonance. Hanslik, for example, though he sees the quality of being facilis tenero ... semper Amori (57) as a 'Kardinaltugend ... des elegischen Dichters', ${ }^{19}$ rejects Burck's characterization of Tibullus' admission to Elysium as 'eine Äußerung seines Dichterstolzes'; ${ }^{20}$ and the later scholar's conclusions are endorsed by D. P. Harmon, who maintains that 'in Tibullus 1.3 Venus conducts her votary to Elysium not to honor him as a great poet but because he is a great lover' ${ }^{21}$ But this dichotomy between lover and poet, between love and poetry, is artificially schematic in the context of Roman love elegy, where the poet's persona is (almost always) the lover, and the sole source of his literary inspiration the puella (cf. Tib. 2.5.111-12; Prop. 2.1.1-16, 2.30B.40; Ov. Rem. am. 764; Martial 8.73.5-10). Furthermore, the emphasis on song as an accoutrement of love (59-60) in Tibullus' Elysium - although, as we have seen, it can be related to earlier, non-erotic treatments of the afterlife-suggests the ideal fusion of love and song that is elegiac poetry. ${ }^{22}$ The scene is thus set for the description of the pious lovers' posthumous activities, which bear a close resemblance to what we may assume to have been their customary pursuits during their earthly existence, ${ }^{23}$ and are expressed in much the same terms as those in which the elegiac lover-poet chronicles the happier moments of his own amatory career. That this accumulation of characteristically elegiac vocabulary cannot be dismissed as coincidental may be seen from a comparison of the terminology of our Tibullan Elysium with that of a later passage,

${ }_{16}$ Maltby ad 63-4; R. Pichon, De sermone amatorio apud Latinos elegiarum scriptores (Paris, 1902), 277-8.

17 Maltby, and Murgatroyd, ad 63-4; Pichon (n. 16), 192.

${ }_{18}$ Cf. Lee-Stecum (n. 2), 119-20; also Cairns (n. 2), 54; Bright (n. 2), 28; Eisenberger (n. 2), 193.

${ }_{19}$ Hanslik (n. 3), 139. For possible poetic connotations of facio and its derivatives in Tibullus see D. Wray, CPh 98 (2003), 217-50.

${ }^{20}$ Hanslik (n. 3), 143, quoting E. Burck, Hermes 80 (1952), 188; also W. Steidle, WS 75 (1962), 118; contra, Moßbrucker (n. 2), 51 (cf. ibid. 53: 'Liebhaber Delias, d.h. elegischer Dichter').

${ }^{21}$ Harmon (n. 2), 1922; see also B. W. Boyd, Ovid's Literary Loves: Influence and Innovation in the Amores (Ann Arbor, 1997), 186.

${ }_{22}$ Cf. Bright (n. 2), 29; Geiger (n. 3), 12 with n. 1, 16; T. D. Papanghelis, Propertius: A Hellenistic Poet on Love and Death (Cambridge, 1987), 134 ('the elegiac ideal, which means ... both elegiac love and poetry'). For music in the underworld, see Nisbet and Hubbard ad Hor. Carm. 2.13 intro.

${ }_{23}$ Maltby, and Smith, ad 63-4; Warden (n. 15), 39, 44; S. Lilja, The Roman Elegists' Attitude to Women (Helsinki, 1965), 172-3. For activity in the underworld as a continuation of earthly life, cf. Verg. Aen. 6.653-5; Ov. Met. 4.443-5; Pascal (n. 4), 53-4; Cumont (n. 4, 1922), 72-3, 138; id. (n. 4, 1949), 68-70; I. A. Richmond, Archaeology, and the After-life in Pagan and Christian Imagery (London-New York-Toronto, 1950), 20. P. Grimal, Rome, la littérature et l'histoire (Rome, 1986), 1.476 with $\mathrm{n}$. 52, wrongly claims that the Greek conception was not taken up in Rome. 
Ovid's heavily programmatic description of the physical attributes of his muse Elegy (Am. 3.1.7-10): ${ }^{24}$

venit odoratos Elegia nexa capillos,

et, puto, pes illi longior alter erat.

forma decens, vestis tenuissima, vultus amantis, et pedibus vitium causa decoris erat.

The literary relevance of Ovid's personification is clear from the disparity of the Muse's feet, which serves only to enhance her charm - an obvious reference to the structure of the elegiac couplet. Elegy's perfumed hair (odoratos ... capillos, 7) recalls the fragrance of the roses (odoratis ... rosis, Tib. 1.3.62) in Tibullus' underworld, and we may note that there too hair-this time the lovers' - is a point of interest (insigni ... coma, Tib. 1.3.66). Her clothing is tenuissima (9), like the Elysian birds who sing tenui gutture (Tib. 1.3.60), only more so-naturally we would expect the genre's personification to embody its distinctive qualities to perfection. Her features are those of a lover (vultus amantis, 9), and the population of Elysium includes 'every lover' (cuicumque ... amanti, Tib. 1.3.65). At the start of Ovid's poem the setting has been established as an ancient and venerable grove where, as in Tibullus, latere ex omni dulce queruntur aves (4), and later on we learn that Elegy clasps in her hand a wand of myrtle (fallor, an in dextra myrtea virga fuit?, 34), the material from which the lovers' garlands are composed in paradise (myrtea serta, Tib. 1.3.66). Finally, the penultimate line of the Ovidian piece calls Venus' offspring - and Ovid's poetry-teneri ... Amores (70), using the same epithet as Tibullus does to describe both Amor singular at 1.3.57 and the girls cavorting in Elysium at 1.3.63.

Although these correspondences cannot tell us whether or not Ovid had our passage of Tibullus specifically in mind, they do at least suggest that the earlier elegist's picture of Elysium can be seen to possess a literary significance within the context of its genre. Tibullus' vision of the rewards awaiting true lovers in the afterlife is, in short, the apotheosis of the elegiac 'life of love' ${ }^{25}$ the lovers' Elysium represents the ultimate fulfilment of the generically enshrined desires of the love elegist, the posthumous realization of elegy's characteristic tropes and aspirations. The perpetual happiness of the iuvenes and puellae on the Elysian plains is a projection of the happier side of the elegiac existence, with all its codification-its tenuitas, its love-making and its militia amoris - on to eternity. The lover in Elysium, rewarded for his receptiveness tenero ... Amori, is the elegiac lover par excellence, able to pursue the 'life of love' in its purest form, without impediment. Tibullus' fantasy is thus almost Platonic in its conception: the imperfections and uncertainties of the lover-poet's

${ }^{24}$ On the figures of Elegy and Tragedy in Am. 3.1, and their function in literary definition, see M. Wyke, The Roman Mistress: Ancient and Modern Representations (Oxford, 2002), 115-54, esp. 119-30; A. M. Keith, 'Corpus Eroticum: elegiac poetics and elegiac puellae in Ovid's Amores', CW 88 (1994), 27-40 at 27-8, 30.

25 On the 'life of love' see R. O. A. M. Lyne, The Latin Love Poets (Oxford, 1980), 65-81; J.-P. Boucher, Études sur Properce (Paris, 1965), 17-35; Lilja (n. 23), 43-109, esp. 43-55, 63-76; L. Alfonsi, 'Otium e vita d'amore negli elegiaci augustei', in Studi in onore di Aristide Calderini e Roberto Paribeni (Milan, 1956), 1.187-209; Burck (n. 20), esp. 163-82. Note also Smith ad 1.3.63-4 'happy love according to the conventional ideal of earthly life as set forth by the elegiac poets'. Campbell (n. 33), 155, describes Tibullus' vision as 'an ideal elegiac world', but does not elaborate; likewise Morelli (n. 3), 182; F. Williams, AJPh 124 (2003), 227 ('the regular ingredients of love elegy'). For parallels between the underworld in 1.3 and Tibullus' portrayal of love elsewhere in his poetry, see generally Geiger (n. 3), 10-21. 
condition on earth are here refined into an ideal of elegiac perfection. The elegist's in his heaven, all's right with the world.

It is in this light that we must interpret the panorama of infernal desolation that follows, its details closely balancing those of the erotic paradise to which it stands in such stark contrast. ${ }^{26}$ Here the impression is of a measureless expanse of blackness, confusion, uproar and torment, confined within the bounds of brazen doors and thundering torrents of murky water (1.3.67-82):

at scelerata iacet sedes in nocte profunda abdita, quam circum flumina nigra sonant:

Tisiphoneque impexa feros pro crinibus angues saevit et huc illuc impia turba fugit;

tum niger in porta serpentum Cerberus ore stridet et aeratas excubat ante fores.

illic Iunonem temptare Ixionis ausi versantur celeri noxia membra rota;

porrectusque novem Tityos per iugera terrae adsiduas atro viscere pascit aves.

Tantalus est illic, et circum stagna: sed acrem iam iam poturi deserit unda sitim;

et Danai proles, Veneris quod numina laesit, in cava Lethaeas dolia portat aquas.

illic sit quicumque meos violavit amores, optavit lentas et mihi militias.

The catalogue of sinners punished for offences committed during their lifetime in the world above introduces a parade of characters familiar from traditional accounts of the tribulations of Tartarus. Having witnessed the elegiac rapture of the lovers in their amatory heaven, we might expect to find a similar eroticization of the inherited inhabitants of Hades, to balance and reinforce Tibullus' reinvention of Elysium. ${ }^{27}$ To some extent, at least, such a contrivance is hardly necessary: as the poet points out (Iunonem temptare ... ausi, 73; Veneris quod numina laesit, 79), a significant number of these stories already involved crimes of passion, and by emphasizing this established motivation in the cases of the first and last examples cited, Ixion and the Danaids, Tibullus succeeds in creating a superficial impression of a hell set aside for trespassers against love. ${ }^{28}$ Tityos too was traditionally held to have attempted an outrage on Leto, so his misdemeanour also fits comfortably into the amatory scheme. It is the penultimate figure in the list, however, Tantalus, who has caused scholars to doubt whether Tibullus' Tartarus can be properly comprehended within such a template. Tantalus is on record as having served up his son to the gods at table, as having divulged the secrets of Zeus, as having stolen nectar from the gods and distributed it among his friends - but there is no truly canonical account of his complicity in any offence against love in surviving classical literature. Does Tantalus' 211

${ }^{26}$ Cf. e.g. Lee-Stecum (n. 2), 122; Moßbrucker (n. 2), 52; Geiger (n. 3), 21-2; Wimmel (n. 2),

${ }_{27}$ Cairns (n. 2), 51, rather curiously reverses the order of the process, for reasons which are not clear: 'It is to parallel and balance this special hell for sinners against love that Tibullus creates before it a heaven especially for lovers'; contra, Griffin (n. 14), 151, n. 32.

${ }_{28}$ Whitaker (n. 3), 73; Bright (n. 2), 31. J. F. G. Cilliers' assertion that because the punishment of the Danaids is accounted for by Veneris quod numina laesit, "neither Ixion, nor Tityus, nor Tantalus can be considered as sinners against Venus in these lines' ('The Tartarus motif in Tibullus' Elegy 1.3', Acta Classica 17 [1974], 75-9, at 78), does not seem to me logically compelling. 
intrusion into this gallery of villains, then, represent a lapse on the part of the poet, a failure of intellectual rigour, ${ }^{29}$ a denial of the specifically erotic nature of Tibullus' Tartarus, ${ }^{30}$ or an interpretative challenge $?^{31}$

The lengths to which critics have gone in seeking to resolve this apparent anomaly together constitute one of the more bizarre footnotes to the history of classical scholarship. Herma Drews, in her 1952 Kiel thesis Der Todesgedanke bei den römischen Elegikern, endeavoured to connect the Tibullan Tantalus with Assaon, a figure from Lydian folklore who seems to have attempted to seduce Niobe. ${ }^{32}$ In 1969 A. A. R. Henderson resorted to the expedient of textual emendation to expel the troublesome Tantalus, arguing that Sisyphus, an equally traditional denizen of the underworld who like Ixion ventured to assault Juno, dropped out in transmission, to be replaced by the present, less appropriate couplet (the justification adduced for this audacious conjecture is the fact that Tantalus 'comes immediately to mind in a Tartarean context'). ${ }^{33}$ For J. F. G. Cilliers, the very conventionality of Tantalus as an inhabitant of Hades is sufficient to guarantee the authenticity of his appearance here, and to rule out any suspicion of Tibullan tampering with this inherited material: 'the Tartarus motif ... is a literary topos which does not indicate unusual treatment by the poet' ${ }^{34}$ But this is a fundamental misunderstanding of the nature of the topos, and of the attitudes of authors and their audience towards conventional material: the topos is not a restriction on the individuality of the poet, obliging him to churn out the same motifs recycled in turn by every other writer on the subject, but rather a challenge to participate in a creative tradition. ${ }^{35}$ And this, as we shall see, is precisely what Tibullus has done - and not just in the case of Tantalus.

It was left to the late Guy Lee, in a note to his translation of the elegy, to propose the explanation for Tantalus' presence in an erotic Tartarus that has met with general acceptance. ${ }^{36}$ The fourth-century A.D. historian Orosius reports in passing the story of Tantalus' abduction of, and subsequent efforts to detain, Ganymede, and gives his source as the Hellenistic elegist Phanocles: ${ }^{37}$ Tantalus rex Frygiorum Ganymedem Troi Dardaniorum regis filium cum flagitiosissime rapuisset, maiore conserti certaminis foeditate detinuit, sicut Fanocles poeta confirmat... There is thus an identifiable precedent for connecting Tantalus with sexual impropriety of a kind that might vindicate his inclusion in a catalogue of amatory offenders such as Ixion and Tityos. Provided that the reader is acquainted with this version of the legend, Tibullus eludes

29 Cf. Cairns (n. 2), 55; Murgatroyd ad 77-8.

${ }^{30}$ Cilliers (n. 28), 78: 'there is no indication that the poet has remoulded this topos to give every separate element in it specific elegiac meaning in order to balance every element in Elysium'.

31 Cairns (n. 2), 55.

${ }^{32}$ H. Drews, 'Der Todesgedanke bei den römischen Elegikern' (unpublished diss., Kiel, 1952), 61. Cf. Cilliers (n. 28), 76; Moßbrucker (n. 2), 52; contra, Eisenberger (n. 2), 194, n. 2, followed by Wimmel (n.2), 211, n. 71.

33 A. A. R. Henderson, 'Tibullus, Elysium and Tartarus', Latomus 28 (1969), 649-53, at 650.

34 Cilliers (n. 28), 79, condemned by Bright (n. 2), 29, n. 46 as 'a shallow reading of the lines'.

35 On the nature of the topos, see S. E. Hinds, Allusion and Intertext: Dynamics of Appropriation in Roman Poetry (Cambridge, 1998), 34- 47.

36 A. G. Lee, Tibullus: Elegies (Cambridge, 1975), 106, followed by Maltby ad 1.3.77-8; Lee-Stecum (n. 2), 123; Murgatroyd ad 1.3.77-8; Bright (n. 2), 31, n. 52. The thesis is championed particularly by Cairns (n. 2), 56-7, with his penchant for things Hellenistic.

37 Oros. Hist. adv. paganos 1.12.4. For Phanocles see N. Hopkinson, A Hellenistic Anthology (Cambridge, 1988), 177-9; H. Lloyd-Jones and P. J. Parsons, Supplementum Hellenisticum (Berlin, 1983), 478-81; A. A. Day, The Origins of Latin Love-Elegy (Oxford, 1938), 24-6. 
the charge of inconsistency, and we have a Tartarus populated by sinners against love to balance his Elysium for lovers.

Yet even if we can postulate a suitably erotic motive for Tantalus' conscription into the ranks of famous sinners balancing the blessedness of the lovers in Elysium, that is not in itself sufficient to validate the claim that Tibullus' is a truly elegiac inferno, given what we have seen of the preceding vignette of his paradiso in lines 57-66. 'The transformation of the Elysian Fields demands a corresponding transformation of Tartarus', ${ }^{38}$ and although the Elysian lovers are designated as such at line 65, and their identity arguably implied in lines 57 and 64, it is their characteristic behaviour and the setting in which this takes place that define the distinctively elegiac nature of the scene. Indeed, the fact that the iuvenes and puellae in Elysium (with the exception, of course, of Tibullus himself) are always referred to collectively suggests that their individual identity is not of primary importance, and we might argue that - despite the debate over the reasons for Tantalus' presence - the same is true of the inhabitants of Tartarus, even though they are singled out by name. Their activity in the underworld is at least as important as the causes of their confinement there, and the poet has seen fit to allocate more space to the torments inflicted on his sinners than to the crimes which have occasioned them-hence the potentially confusing ellipsis of motive in the case of Tantalus (and, in fact, that of Tityos too, though the more immediately apparent eroticism of his offence has meant that this omission has attracted less comment).

The elegist is careful to establish the atmosphere of Tartarus before introducing its residents to his readers: the introductory couplet, with its subterranean darkness and tumultuous rivers, piles up epithets and imagery traditionally associated with the nether world in literature and familiar from epitaphs. ${ }^{39}$ Like the birds, flowers and spices of Elysium, then, but without the innovation of Venus $\psi v \chi 0 \pi \circ \mu \pi o ́ s$, we have here a preliminary indication of setting that appeals to the Roman reader's prior acquaintance with conventional ways of visualizing the underworld. The departure from orthodoxy begins in the next line with the advent of Tisiphone, by this date a fully paid-up member of the Tartareans, ${ }^{40}$ but here with a striking new twist: at line 69 of the present poem she is said to have fierce snakes in place of her hair, pro crinibus, rather than entwined in her (presumably otherwise normal) coiffure. ${ }^{41}$

Once again editors have responded to this challenge to their expectations by clutching at the consolation of a variant reading. Failing to see the relevance of the fury's serpentine locks being 'uncombed' (impexa), certain manuscripts give the participle as implexa - that is, Tisiphone is 'interwoven' with snakes in place of (by implication some of) her hair. ${ }^{42}$ But there is considerable dramatic point in our being told that Tisiphone's serpentine locks have not been subjected to any form of grooming. We may recall, first, that the last detail to be added to the picture of lovers in Elysium was that of their hair (coma, 66), insignis with its wreath of myrtle - so now we have a specific contrast between the splendid locks of the lovers and the hideous disarray of this hellish agent of torture. ${ }^{43}$ Bright observes that 'Tibullus

38 Campbell (n. 3), 155.

39 See e.g. Murgatroyd ad 1.10.37-8; Brelich (n. 14), 16; E. Galletier, Étude sur la poésie funéraire romaine d'après les inscriptions (Paris, 1922), 47-8; Cumont (n. 5), 59-60; Garland (n. 4), 51.

40 Cf. e.g. Apollod. 1.1.4; Hor. Serm. 1.8.33-4; LIMC 3.1 s.v. ERINYS, 64.

41 Bright (n. 2), 30, n. 47, followed by Lee-Stecum (n. 2), 122.

${ }^{42}$ For discussion see G. K. Galinsky, Mnemosyne, 4th ser., 26 (1973), 163-4, and commentators ad loc. The same textual problem surfaces at Verg. G. 4.482 (again relating to the Furies in Tartarus).

43 Galinsky (n. 42), 164; Maltby ad 69-70. 
speaks of hair more often than any other poet, using it as an indication of character as well as a descriptive detail', and it is a short step to deduce from the condition of her hair the essence of Tisiphone's character as 'freedom perverted into destructive anarchy'. ${ }^{44}$ As presiding goddess of this region of the underworld, ruthlessly driving the shades of the wicked in confusion before her, Tisiphone might also be seen as a counterbalance to the figure of Venus in line 58, who leads her willing votaries into the happiness of Elysium.

Whilst all these implications are undoubtedly present, it is tempting to see in this portrait of a sadistic dominatrix striking terror into those around her a further analogy, namely with the hard-hearted mistress of elegy who drives away her admirers; the detail of impexa meanwhile contrasts Tisiphone with the elegist's ideal of his beloved, whose hair is an important part of her attraction. ${ }^{45}$ For the generic connotations we might compare once more the opening poem of Amores 3, where Elegy is pictured odoratos ... nexa capillos (3.1.7), distinguishing the goddess from her opposite number Tragedy, with fronte comae torva (12) and densum caesarie ... caput (32). So Tisiphone is vilified not just for having snakes instead of hair, but also for her neglect of their appearance (though one can understand why she might have had difficulty securing the services of a suitable Cypassis ...), and this, combined with her tendency to wreak havoc among those who approach her, makes her the very worst kind of puella.

The elegiac tone intensifies as we move further into the scelerata sedes. At the door sits Cerberus, the adjective niger (71) pointing to his Tartarean nature and colouring (cf. flumina nigra, 68), his hissing serpentum ... ore recalling another traditional attribute of the hound of hell. ${ }^{46}$ The language in which his vigil is described (excubat ante fores, 72), however, can scarcely fail to evoke the position of the prostrate lover-poet of elegy before his mistress' bolted door (cf. Tib. 1.1.56, sedeo duras ... ante fores) - although there is perhaps a hint here too of the custos whose vigilance thwarts the lover's attempts to gain admission. ${ }^{47}$ In either case, Pluto's pet comes to stand for one of the most characteristic miseries of the elegiac experience. Likewise Ixion, the first of the sinners to be rolled out, with his unequivocally erotic offence (temptare, $73)^{48}$ and lasting attachment to the wheel of his torment (celeri ... rota, 74), mirrors on a literal level a common metaphor for the constant tribulations attendant on the

44 Bright (n. 2), 74, 30, n. 47, followed by Lee-Stecum (n. 2), 122. Also relevant are K. McNamee's comments ('Propertius, poetry, and love', in M. DeForest [ed.], Woman's Power, Man's Game: Essays on Classical Antiquity in Honor of Joy K. King [Wauconda, 1993], 215-48, at 224-5) on the poetic significance of hair in Propertius; cf. N. Holzberg, Ovid: The Poet and His Work, trans. G. M. Goshgarian (Ithaca-London, 2002), 52-3; J. E. G. Zetzel, MD 36 (1996), 73-100, at 77-81, 100, on Ovid. For the Furies as an embodiment of human passions, see Cumont (n. 4, 1922), 78, 181.

45 See Tib. 1.5.43-4, 1.8.9-10; Prop. 2.1.7-8, 2.2.5, 2.3.13, 2.22.9, 3.10.14; Ov. Am. 1.5.9-10, 1.7.11-12, 1.14, 2.4.41-3, 3.3.3-4.

46 Wimmel (n. 2), 210 with n. 68; LIMC 6.1 s.v. Kerberos. See later Verg. Aen. 6.419; Hor. Carm. 3.11.17-18; Ov. Her. 9.93-4, Met. 10.21-2; [Verg.] Culex 221.

47 exclusus amator: Bright (n. 2), 30; Harmon (n. 2), 1920; Lee-Stecum (n. 2), 122, 125, n. 55. custos: Lee-Stecum (n. 2), 122, n. 46. Campbell (n. 3), 155, remarks generally on the 'elegiac terms' in which Cerberus' vigil is portrayed; while for K. Bassi, Syllecta Classica 5 (1994), 58, Tibullus' posture as excluded ianitor at 1.1.55-6 itself suggests a correspondence with 'Hell's gatekeeper'. Maltby ad 1.3.71-2 contrasts the fores of Tibullus' dystopian Hades with the lack of fores in the Golden Age at 1.3.43.

48 Murgatroyd ad 73-4; OLD s.v. tempto 9b; Pichon (n. 16), 276. 
lover's condition, the rota amoris (omnia vertuntur: certe vertuntur amores: / vinceris a victis, haec in amore rota est, Prop. 2.8.7-8). ${ }^{49}$

It is not immediately clear how the second sinner, Tityos, fits into this scheme. The detail of his nine iugera is conventional (see Hom. Od. 11.577; Lucr. 3.988; Prop. 3.5.44; Verg. Aen. 6.596-7); also inherited is his Promethean torment by hungry birds, which constantly devour his self-regenerating liver. ${ }^{50}$ Although Tibullus uses the nonspecific atro viscere (76) for the part of Tityos consumed by the birds, if we assume that the phrase stands for the traditional locus of the liver it may be relevant that this organ was sometimes seen in antiquity as the seat of the passions; ${ }^{51}$ Tityos' crime passionnel is thus rewarded with treatment that reflects the perpetual anguish caused to the lover by the tyranny of his emotions. That is certainly the interpretation of this infernal figure offered by an influential strand of allegorical exegesis which we may assume to have been well known to Tibullus' first audiences. Lucretius' De rerum natura can scarcely be seen as a generic model for Latin love elegy, even with the tirade against romantic love that concludes its fourth book (4.1058-1287); but, as perhaps the most recent and most extensive account of the terrors of Tartarus in Latin literature prior to Tibullus' third elegy, it is likely that the discovery of Tityos in the midst of a review of sinners against love would have prompted contemporary readers to remember Book 3 of Lucretius' poem (3.992-4):

sed Tityos nobis hic est, in amore iacentem quem volucres lacerant atque exest anxius angor aut alia quavis scindunt cuppedine curae.

The association of Tityos with the miseries of the lover is thus backed by the full force of Lucretian authority, and the anxius angor he suffers is an inevitable result of the chasm between elegiac ideal and importunate reality: Tityos, like Tisiphone and Cerberus, is an example of what happens when the 'life of love' goes wrong.

The everlasting thirst of Tantalus (acrem ... sitim, 77-8) was as proverbial in antiquity as it is today, appearing first in Homer ( $O d .11 .582-92)$, where he stands in a lake up to his chin, trying endlessly to drink, while the wind snatches exquisite fruits from his grasp. In Lucretius (3.980-3) he is subjected to a different torment, but there is nonetheless, as in the case of Tityos, a Lucretian precedent for the lover's being quite literally 'tantalized'. In the course of his disquisition on the folly of romantic love, Lucretius compares the insatiability of the infatuated lover to dreams of unquenchable thirst in mid-stream, without naming the most famous victim of this condition (4.1097-102): ${ }^{52}$

ut bibere in somnis sitiens quom quaerit, et umor non datur, ardorem qui membris stinguere possit, sed laticum simulacra petit frustraque laborat

49 See also Tib. 1.5 .70 (celeri ... orbe rotae, as here); Plaut. Cist. 206-7 (versor / in amoris rota); Ar. Lys. 845-6; F. Spoth, Ovids Heroides als Elegien, Zetemata 89 (Munich, 1992), 143 with n. 3.

${ }_{50}$ Hom. Od. 11.576-81; Lucr. 3.984-94; Verg. Aen. 6.595-600 (with just one vultur. cf. Austin ad 6.597).

51 Maltby, and Murgatroyd, ad 75-6; Bright (n. 2), 31; Austin ad Verg. Aen. 6.598; Servius ad Aen. 6.596 (on Tityos). On viscera, see J. André, Le vocabulaire latin de l'anatomie (Paris, 1991), 202-3.

52 See M. R. Gale, Myth and Poetry in Lucretius (Cambridge, 1994), 184; Brown ad 4.1097-1104; and cf. Hor. Serm. 1.1.68-72, where Tantalus ... sitiens appears as a (non-erotic) moral exemplar. Note also the use of the same image at Prop. 1.9.15-16, where the point at issue is inability to write love poetry. 
in medioque sitit torrenti flumine potans, sic in amore Venus simulacris ludit amantis, nec satiare queunt spectando corpora coram...

Tantalus' inclusion in the Tibullan Tartarus is significant as much for its exposition of his punishment, in which the metaphorical 'thirst' of the frustrated admirer, ${ }^{53}$ always just on the point of (iam iam, 78) achieving his desire, is translated into literal and mythological terms, as it is for its recondite amatory motive in his abduction of Ganymede. Indeed, it is possible that the existence of this interpretation of Tantalus' torment - rather than Phanocles' esoteric variant on his criminal career-was the principal motive behind his presence in the underworld here.

The last item in Tibullus' roll-call of wrongdoers is the Danai proles (79), the forty-nine daughters of Danaus who slaughtered their husbands at their father's bidding and thereby collectively Veneris ... numina laesit (79). As with Ixion, the erotic aspect of their crime is specified by the poet; but it would be surprising, in view of our preceding analysis, if there were not also some elegiac slant to their travail in the underworld, which consists in transferring water into leaking urns (in cava ... dolia portat aquas, 80). What this elegiac slant might be is not perhaps apparent at first sight (incontinence is not a venereal disease), but if we bear in mind the Lucretian heritage of the explanations offered for the labours of the two previous malefactors, we are directed back to that poet's final example of allegorized sinners, which happens to be the Danaids (3.1003-10):

\footnotetext{
deinde animi ingratam naturam pascere semper atque explere bonis rebus satiareque numquamquod faciunt nobis annorum tempora, circum cum redeunt fetusque ferunt variosque lepores, nec tamen explemur vitai fructibus umquamhoc, ut opinor, id est, aevo florente puellas quod memorant laticem pertusum congerere in vas, quod tamen expleri nulla ratione potestur.
}

Accusations of ingratitude and covetousness, especially against aevo florente puellae, are hardly rare in Roman love elegy. omnia ... ingratae perierunt credita menti, wails the jilted Catullus (Cat. 76.9), and Ovid promises he will shower his mistress with gifts on condition that she stops asking for them (Am. 1.10.63-4). Indignation at the puella's insistence on being wooed with material enticements is arguably too common a topos within the elegiac genre to need exemplification here; suffice it to say that, for the student of the Ars amatoria, hoc opus, hic labor est, primo sine munere iungi (Ov. Ars am. 1.453). The sieve-like vessels of the Danaids might, then, be seen as a parallel to the limitless cupidity so typical of the mercenary puella of elegy, a shortcoming as offensive to the divinity of Venus as the legendary massacre of the sons of Aegyptus by their brides. There is ample evidence, therefore, both in the symbolic nature of their torment and in their mythological background, to detect in Tibullus' Danaids the type of 'the hard-hearted and unfaithful mistress' ${ }^{54}$

In this way, drawing on Lucretius' famous dictum that, so far as the horrors of the world to come are concerned, in vita sunt omnia nobis (3.979), ${ }^{55}$ Tibullus constructs an

${ }^{53}$ For the erotic sense of sitis, see Pichon (n. 16), 264 - though he gives no examples earlier than Ovid's Remedia amoris.

${ }^{54}$ Henderson (n. 33), 649.

55 Cf. Lee-Stecum (n. 2), 124-5: 'Just as Lucretius claims, the poet constructs his Hell (and his Elysium) in the image of what he has experienced during life' (125). 
elegiac hell that embodies all the wretchedness of unhappy love-and more. The radiant puella of the poet's dreams becomes the grotesque perversion of Tisiphone with her uncombed snakes, the implacable custos (or even the lover himself) turns into a hissing hellhound, and so on. This nightmarish scenario acts as a counterweight to the idealization of the 'life of love' in the eroto-elegiac heaven to which Tibullus imagines Venus will conduct him. His use of the third book of De rerum natura, a monumental work of earnest proselytism, to create a place of posthumous torment for the enemies of romantic love (as Lucretius himself had been) must carry at least a hint of irony. ${ }^{56}$ The principal literary purpose of this tour of the afterlife, however, is to define the character and objectives of Tibullan elegy-after the rural paradise of the opening poem (in which Delia and love play no small part) and the doubt and despair of the second, the poet uses this point in his third elegy to outline and immortalize the preferences and concerns of his genre. The polarity between the ideal lifestyle of Elysium and the correspondingly unrelieved misery of Tartarus allows him to express these in a comparatively 'abstract' manner without deviating from the narrative and thematic structure of the poem. ${ }^{57}$

Finally, Tibullus wishes the terrors of his erotic Tartarus on all those who venture to defile his love, quicumque meos violavit amores (81). The presence of these rivals at the end of his catalogue of mythological sinners serves to balance the elegist's introduction of himself at the start of his tour of Elysium: as Tibullus, facilis tenero ... semper Amori (57), takes first place among the blessed, so his opponents in love are relegated to the deepest recesses of the damned. Subsequent elegy makes wishing amatory misfortune on an enemy into something of a topos (hostibus eveniat lenta puella meis, Prop. 3.8.20), ${ }^{58}$ and the curse of eternal torment in a horribly perverted 'afterlife of love' might well be seen as the ultimate example of such an imprecation. Here too the specifically elegiac character of the Tibullan Tartarus is apparent. The motivation ascribed to the unnamed malefactor(s) is unquestionably erotic, and what they themselves have wished on Tibullus is exclusion from enjoyment of his love, here effected and represented by protracted military service (lentas ... militias, 82), the antithesis of Tibullus' elegiac lifestyle (see Tib. 1.10). ${ }^{59}$ So it is only natural that the lover-poet should retaliate by consigning his detractors (literary and/or erotic, given the double reference of amores [81] to both love and love poetry) to the Tartarean torments of the unhappy lover. It is not uncommon, indeed, to find Tibullus' poetic rival Propertius comparing the miseries of his elegiac existence to the sufferings of Tantalus, Sisyphus and the Danaids (Prop. 2.1.65-8, 2.17.5-10) - a far cry from the Elysian reception complacently anticipated by the lover of Delia. ${ }^{60}$

${ }^{56}$ Henderson (n. 33), who sees the whole passage as 'an elegiac poet's credo, directed against Lucretius' (652), arguably overplays the polemical aspect of Tibullus' use of the De rerum natura.

57 Cf. Morelli (n. 3), 185: Tibullus' poem 'nella descrizione oltretombale ha infatti un valore didascalico ... poiché il mondo che egli descrive non è mai reale ma virtuale, progettuale'.

${ }_{58}$ Cf. also Prop. 2.4.17, 2.9.47-8, 2.16.13-14, 3.9.37-8, 3.20.25-30; Ov. Am. 2.10.16-18, Her. 16.219-20; L. C. Watson, Arae: The Curse Poetry of Antiquity (Leeds, 1991), 145-7.

59 In view of the distinctively elegiac connotations of lentus (Pichon [n. 16], 186; OLD s.v. lentus 8) and militia (Prop. 1.6.30; Ov. Am. 1.11.12, 2.12.27-8, 3.7.68, Ars am. 2.674), and of the seducer's transparently erotic motives, it is tempting to read lentas ... militias (82) as not just 'long campaigns' in the conventional military sense, but also 'dispassionate campaigns' in the warfare of love (militia amoris).

${ }^{60}$ For Tibullan complacency vs. Propertian torment cf. R. O. A. M. Lyne, 'Propertius and Tibullus: early exchanges', $C Q 48$ (1998), 519-44, at 529 with n. 40, 533, 536, 538; id. (n. 25), 184-5. 
Tibullus' combination of eroticism and literary self-definition was to set the pattern for all subsequent elegiac explorations of the underworld, from Propertius' tableaux of glamorous, tearful heroines in the realm of Persephone (Prop. 2.28.49-56, 4.7.55-70) to Ovid's travesty of the motif in the avian Elysium populated by his girlfriend's dead parrot and its feathered friends in Amores 2.6. A similar conception may have appeared - perhaps even in a programmatic context - in the poetry of the elegists' predecessor Gallus, if the latter's own material is reflected in Propertius' imagery at Prop. 2.34.91-2, et modo formosa quam multa Lycoride Gallus / mortuus inferna vulnera lavit aqua. ${ }^{61}$ Rarely, however, in the work of the surviving elegists do we find a vision of the afterlife as comprehensive or as compelling as Tibullus' first foray into the agony and the ecstasy of the world beyond.

University College London

L. B. T. HOUGHTON 1.houghton@ucl.ac.uk

${ }^{61}$ See e.g. Rothstein ad Prop. 2.34.91; L. Nicastri, Cornelio Gallo e l'elegia ellenistico-romana (Naples, 1984), 29, n. 25; Papanghelis (n. 22), 68, n. 46, 181, n. 85; Lyne (n. 60), 527, n. 33. The similarity of Propertius' phrasing in these lines to a surviving fragment of Euphorion (fr. 43 Powell) may point to an earlier imitation of that neoteric poet on the part of Gallus: E. Courtney, The Fragmentary Latin Poets (Oxford, 1993), 261-2. 